\title{
The Maintenance for the Security of Socialist Ideology under the Background of New Media
}

\author{
Jingying Jia, Lijiao Li \\ Yunnan University of Traditional Chinese Medicine, Kunming City, Yunnan Province, 650500, China
}

Keywords: new media; socialism; ideological security; maintenance

\begin{abstract}
The rapid development of new media technology and the explosive growth of media information not only provide a new opportunity for the development of Marxist ideology, but also constitute a strong impact on the security of socialist ideology in China. Based on the author's learning and practical experience, this paper first analyzes the characteristics of information dissemination in the new media era, and then discusses the challenges of new media communication to the ideological security in China, finally, and puts forward the countermeasures to safeguard the ideological security in the new media era.
\end{abstract}

\section{Introduction}

New media is a general term for modern means of information dissemination relative to traditional media such as newspapers, radio, television and outdoor advertising. It uses digital technology, network technology, mobile technology, Internet, wireless communication network, satellite and other channels, as well as computers, mobile phones, digital television and other terminals, to provide users with a variety of new channels of information. No matter how people define new media, one thing is certain: its functions, types and ways of acting are constantly changing and extending relative to traditional media. Nowadays, new media has become an important platform for ideological and cultural exchange and ideological contest. How to maintain the ideological security of our country has become an important subject we must face and solve urgently?

\section{The Characteristics of Information Dissemination in the New Media Era}

\subsection{The super interactivity from time to time}

The strong interactivity of new media is mainly reflected in the two-way mobility of information dissemination. Compared with the one-way flow of information in traditional media, the audience of new media can always participate in the process of information dissemination from passive acceptance to active participation in communication. People can not only use their mobile phones to publish information to the media through WeChat, Weibo and forums, but also can read and participate in comments and discussions as visitors to all kinds of information from time to time. Based on this super interactive mode, people can get a strong sense of participation and stimulate their enthusiasm for participation.

\subsection{A huge amount of shared information}

The rapid dissemination of new media information is based on the mass information sharing of the network. It can retrieve the needed information from the vast network resources and process the dissemination. The vast network information can satisfy the new media communication demand no matter in breadth and depth. The information transmitted by the new media can meet the needs of different groups of people, so that different people can find the exciting point in the new media, trigger resonance, and then produce the cluster effect.

\subsection{Hypertext property}

The new media information is spread through the mobile communication terminal on the basis of 
the massive shared resources of the network media. It integrates text, pictures, audio and video, so it greatly surpasses the form of information dissemination by traditional media. Information has a strong transmission, image and interest, attracting the attention of the vast number of young and middle-aged groups, as well as some teenagers and middle-aged and elderly people. The information dissemination in the new media era can provide a broader vision platform for people compared to the traditional media.

\subsection{Convenient cluster platform}

The traditional media information dissemination method can be summarized simply as opposite to the point, and the publication and distribution of its information is based on popular taste, so it is difficult to consider the issue of individuation. In the context of the new media age, based on big data analytical technology, new media can obtain people's preferences through data analysis, push different information to different groups of people according to people's profession and specialty.

\section{The Challenges of New Media Communication to the Ideological Security in China}

\subsection{New media communication increases the defense difficulty of mainstream ideology security}

The great change brought by the new media is a huge challenge to ideological security and defense. First of all, everyone can be the publisher and disseminator of information, and everyone can express their views and ideas, which greatly expands the scope of ideological security defense. It makes it harder to find information that undermines ideological security. Secondly, the rapid and convenient dissemination of information in the new media era has greatly reduced the cost of dissemination, facilitated people's lives and broadened their horizons, but for those who do not have a firm belief in communism, their guiding ideology began to waver and gradually moved towards pluralism, which reduced the defense strength of ideological security.

\subsection{New media communication dispels the recognition for mainstream ideology}

In the new media era, people can use network media, mobile media and other means of communication to spread their views and ideas and report live whenever and anywhere. Because each individual's objective growth environment and subjective position are different, the content of the information they publish and disseminate is very strange, and everyone's views vary greatly, which caused the new media environment in the concept of mixed and complex. Information redundancy is often accompanied by fragmentation of knowledge, impetuosity in pursuit and superficial thinking, which weakens people's judgment and selectivity on whether values are right or not, and it is more easily accepted by some people, such as extreme individualism, pragmatism, hedonism, decadence, etc. The strength of the socialist ideology against the impact of foreign erroneous thoughts was dispelled. The uncontrollable nature of new media information dissemination increases the cost and difficulty of the government in maintaining the mainstream ideology. Once the non-mainstream ideology is formed and spread, it will inevitably impact the social identity of the mainstream ideology.

\subsection{New media dissemination is not conducive to ideological information security supervision}

For the purpose of personal interest, some people or organizations leak, destroy and infiltrate the ideological security information in our country. They use new media to promote anti-social speech, and even use new media to carry out political subversive activities, which seriously endangered the public interest of the state and the legitimate rights and interests of citizens. For domestic and foreign anti-China separatist forces, hostile forces, cults and terrorist organizations, etc., they use many kinds of software to encrypt emails and release a lot of demagoguery negative information about our country. At present, the supervision mechanism of network ideology security is not perfect, and the investment of network information security supervision is low, so network worms, hacker attacks, spyware manipulation of the network incidents occur frequently. 


\subsection{The credibility of government will decline and the authority of the ideological work will be challenged}

Judging from the current situation of the development of new media in China, the credibility of the government and the authority of ideological work are challenged. First of all, some ambitious and interest groups with ulterior motives may use the new media to publish the negative and false news for the government on the Internet, to confuse and incite the people, and wantonly to denigrate the government. It has seriously hurt the enthusiasm of the broad masses of the people who love their country and the Party. Secondly, some West countries make use of the convenience and low threshold of new media to infiltrate our country's ideology through new media, exaggerating the normal problems in the transition period. And all the causes of the problem are pushed to the CPC and the Chinese government, so that the positive image of the CPC and the government is damaged.

\section{The Countermeasures to Safeguard the Ideological Security in the New Media Era}

\subsection{To enhance the ideological leadership, dredging and integration of new media space}

The essence of ensuring the security of the mainstream ideology of new media space is to use Marxist ideology to lead various trends of thought in the dissemination of new media. Focus on strengthening the monitoring for new media space hot spots, analysis and judgment, rapid response, communication guidance, summary analysis and accountability supervision, involving groups such as WeChat, Weibo and other microspaces and forums, posts, etc. Improve the new media public opinion to guide the multi-party linkage mechanism and the government network news fast release system. The promotion of ideological leadership, dredge and integration in new media space is essentially a human problem. Only by strengthening the construction of the new media space ideological work team, enhancing the personnel's network technical ability and public opinion guiding ability, perfecting the examination mechanism and incentive mechanism of the new media space ideology work, cultivating a group of faith strictly, the ideological propaganda and guiding team with high quality and strong business can fundamentally enhance the ideological security defense of the new media space.

\subsection{To perfect the legislation and enforcement mechanism of new media network laws and regulations}

The Government should solve the problems in the reform by law thinking and legal means. This has the directive enlightenment to us to manage the new media space ideological security disorder. First, to speed up the legislation and introduce new media laws and regulations on new media, so we can build a systematic normative system of laws, administrative regulations, departmental regulations and judicial interpretations. Secondly, it is necessary to strictly enforce the law and improve the system of responsibility for cases and the system for reverse investigation, strengthening the legal administration of new media by ensuring that the law is truly enforced. For illegal acts of new media communication, we should increase the intensity of investigation and exposure, and eventually form a deterrent to criminals. For the illegal elements who use new media to publish anti-party, anti-socialism and slander national image, legal responsibility must be investigated according to law. Finally, we should fully implement the real name system. For citizens who use new media, they should input their IP address and personal real information of SIM card into the new media management system. It is necessary to enter the personal identity information on the Internet, and the information can only be authorized by the relevant supervision department, and the security agreement can be signed to be used. It can not only protect the personal privacy of the Internet users, but also supervise the suspicious Internet users in an all-round way, which will greatly enhance the effect and intensity of supervision.

\subsection{To make full use of the new media platform and propagate the socialist core values}

For the powerful influence and advantage of new media communication, we should study and make use of it, and make the new media a platform for the party and the government to display a 
good image. In the network media, we should be good at using Weibo, forums, posts and portals to introduce and propagate socialist core values in various forms, such as video, audio, pictures and texts, so as to form a three-dimensional effect. In particular, for Weibo, the influential communication tool in the network media, we should set some special funds and organizations to guide the trend of thought in public opinion and propagate the core values.

\subsection{To smooth the channels of communication between the government and the people to} safeguard the reputation of the government

First, it is necessary to strengthen self-discipline with the aim of setting an example for the masses. When communicating and doing business affairs, we should strictly request themselves, treat them seriously and sincerely help the people to solve the problems and improve the image of the government. Second, it is necessary to enhance their own understanding for new media communication. We should be good at using new media to disseminate the latest achievements of socialism with Chinese characteristics and the Party's various lines, principles and policies with an open and progressive mentality. Third, we should understand the skills, rules and characteristics of new media communication, which are different from the traditional communication channels.

\section{References}

[1] Zheng Shufen, Yan Mingming. The path Choice of the Construction of ideological Security in China in the New Media era[J]. Discussion on the Theory, 2017, (04): 138-142.

[2] Wang Jingyun. The impact of new media on ideological security in China's colleges and universities and its countermeasures[J]. A study of ideological Education, 2017, (04): 104-107.

[3] Wang Guangsheng. Study on the influence of New Media on the ideological Security of China and its Countermeasures[J]. Journal of Party School of Hefei Municipal Committee of the Communist Party of China, 2017, (02): 11-14.

[4] Yang Yongzhi, Zhang Yan. On the maintenance of ideological Security in China in the New Media era[J]. Theory and Modernization, 2012, (06): 37-41. 